Review

\title{
A Systematic Review to Identify the Effects of Biologics in the Feet of Patients with Rheumatoid Arthritis
}

\author{
Laura Ramos-Petersen ${ }^{1} @$, Christopher James Nester ${ }^{2}$, Andres Reinoso-Cobo ${ }^{3}$, Pilar Nieto-Gil ${ }^{4}$, \\ Ana Belen Ortega-Avila ${ }^{3,5, *(1)}$ and Gabriel Gijon-Nogueron ${ }^{3,5}$ (i) \\ 1 Department Podiatry, Universidad Católica San Antonio de Murcia, 30107 Murcia, Spain; \\ lrpetersen@ucam.edu \\ 2 School of Health \& Society, University of Salford, Salford M5 4WT, UK; C.J.Nester@salford.ac.uk \\ 3 Department Podiatry, University of Malaga, Arquitecto Francisco Penalosa 3, 29071 Malaga, Spain; \\ andreicob@uma.es (A.R.-C.); gagijon@uma.es (G.G.-N.) \\ 4 Department of Nursing and Podiatry, University of Valencia, 46010 Valencia, Spain; pilar.nieto@uv.es \\ 5 Instituto de Investigación Biomedica de Malaga (IBIMA), 29071 Malaga, Spain \\ * Correspondence: anaortavi@uma.es
}

check for updates

Citation: Ramos-Petersen, L.; Nester, C.J.; Reinoso-Cobo, A.; Nieto-Gil, P.; Ortega-Avila, A.B.; Gijon-Nogueron, G. A Systematic Review to Identify the Effects of Biologics in the Feet of Patients with Rheumatoid Arthritis. Medicina 2021, 57, 23.

https://doi.org/10.3390/

medicina57010023

Received: 17 November 2020

Accepted: 26 December 2020

Published: 29 December 2020

Publisher's Note: MDPI stays neutral with regard to jurisdictional clai$\mathrm{ms}$ in published maps and institutional affiliations.

Copyright: $\odot 2020$ by the authors. Licensee MDPI, Basel, Switzerland. This article is an open access article distributed under the terms and conditions of the Creative Commons Attribution (CC BY) license (https:// creativecommons.org/licenses/by/ $4.0 /)$.

\begin{abstract}
Background and Objective: Ninety percent of patients with rheumatoid arthritis (RA) feel foot pain during the disease process. Pharmacological treatment of RA has a systematic effect on the body and includes: Nonsteroidal anti-inflammatory drugs, disease-modifying antirheumatic drugs (DMARDs) and biologics. The objective of our review was to examine the impact of biologics on patients with RA 'foot. Methods and Material: A systematic review of randomized control trials and observational studies that evaluated the efficacy of biologics against other pharmacological treatment, and included a foot outcome measure. The search covered MEDLINE Ovid, Pubmed, CINAHL, Cochrane Library, Evidence Search, and Web of Science. Risk of bias was evaluated using Cochrane guidance and the Newcastle Ottawa Scale adapted version. Results: A total of eight studies fully met the inclusion criteria: Three randomized control trials, and five observational studies were the basis of our review. A total sample of 1856 RA patients with RA treatment participated. The use of biologics was not associated as a risk factor for post-operative surgical site infection or delayed wound healing. The benefits of biologics, in terms of the disease evolution, were assessed using X-ray. Conclusion: Evidence suggests that the use of biologics is not a risk factor for post-operative surgical site infection or delayed wound healing. The use of biologics presents benefits in terms of the disease evolution assessed through X-ray.
\end{abstract}

Keywords: biologics; DMARDs; feet; rheumatoid arthritis; systematic review

\section{Introduction}

Rheumatoid arthritis (RA) is a musculoskeletal disorder with a chronic inflammatory autoimmune condition that commonly affects foot joints, ankles, knees, and wrists [1]. It impairs normal daily life, affects body image and personal relationships, and therefore, also impacts the quality of life [2-4]. There is, consequently, a significant social and economic cost [4]. Foot involvement and foot joint pain are signature features of early RA and almost omnipresent during the progress of the disease, with subsequent physical and psychosocial impairment [5,6]. The prevalence of foot pain increases with disease duration, affecting $90 \%$ of people with RA at some stage [7,8]. The current strategy, as defined by the RA guidelines, is a treat-to-target strategy. The purpose of this strategy is to treat active RA to achieve a target of remission or lower disease activity in cases that remission cannot be achieved. The RA guidelines also state that it is important to always consider people's rights to be involved in discussions and make informed decisions about their care. The purpose is to provide pain relief, preserve physical activity, and quality of life $[9,10]$. Treatments include pharmacological agents, but also footwear, foot orthoses, and sometimes surgery [11]. 
Nonsteroidal anti-inflammatory drugs (NSAIDs) are commonly used, but do not modify the disease evolution. In contrast, disease-modifying antirheumatic drugs (DMARDs) have the capacity to slow disease progression (including methotrexate (MTX), sulfasalazine (SSZ), and leflunomide [12]). These can alleviate patient symptoms, and if used early in the RA process, can enable better longer-term outcomes [13]. Biologics are a special type of DMARD, and they can help in terms of limiting radiological damage by inhibiting joint destruction and suppressing inflammation [14-16]. However, some patients do not respond to pharmacological treatments, or initial responses may reduce and efficacy changes over time. Regardless, any treatment has the capacity as an anti-RA strategy if it inhibits hyperplasia of synovial cells $[17,18]$. A previous systematic review concludes that compared with DMARDs alone, biologics, in combination with DMARDs achieve a 50\% reduction of joint destruction [19]. Regarding to biologics, they have shown significant contribution in aiding the reduction of inflammation and articular destruction [20], which may indicate clinical benefits in terms of the feet of RA patients. A systematic review of the influence of biologics effects on RA patients in general pain, concluded that biologics are clearly effective in pain relief, improving functional status, and preventing structural joint damage [21]. A prior qualitative study about foot impairments in RA patients with biologics described various participation limitations related to foot problems, such as foot impairments influencing work or foot obstacles in domestic life, [22] without any foot pain mentioned. However, the effect of biological treatments on the foot is not well-known, since there are not many randomized control trials (RCTs).

A recent meta-analysis of evidence related to footwear and orthoses has evidenced their efficacy in relation to the reduction of foot pain and associated disability and increased quality of life [23]. A similar appraisal of the literature concerning pharmacological treatments has not been published. The objective of our systematic review was to explore biologics effects in patients with rheumatoid arthritis in terms of their feet.

\section{Materials and Methods}

Review registration number: PROSPERO CRD42019137893.

This review was performed following the Preferred Reporting Items for Systematic Reviews and Meta-Analyses (PRISMA) statement [24].

\subsection{Search}

Studies were analyzed under the PRISMA guidelines [24], and a search was carried out from inception using the following databases: MEDLINE Ovid, Pubmed, CINAHL, Cochrane Library, Evidence Search, and Web of Science. A previous scoping search was carried out to ensure that this aim had not been addressed by previous studies, and PROSPERO and Cochrane Library were explored. The last search was run on 9th April 2020 by one reviewer. The following Mesh terms were used to identify relevant clinical trials: "Arthritis" [MeSH Terms], "Rheumatoid" [MeSH Terms], "Foot" [MeSH Terms], "biologics" [MeSH Terms], "biological therapy" [MeSH Terms] (Appendix A).

Eligibility criteria, study selection, and data collection process:

We reviewed studies that assessed the efficacy of biologics therapy in terms of RA patients' feet. All studies conducted the following PICO structure [25]:

- $\quad \mathrm{P}$ (population) $=$ female and male patients with RA, aged $>18$ years.

- I (intervention) $=$ efficacy of biologics treatment in terms of RA patients' feet.

- $\quad \mathrm{C}$ (comparator) $=$ other type of pharmacological or conservative treatments.

- $\mathrm{O}$ (outcome) = evaluation of biologics effects on RA patients 'feet, as the modified Sharp-van der Heijde (SvdH) score [26] or the use of the Guideline for the Prevention of Surgical Site Infection [27] or any aspect that directly affects the measurement of the foot.

No publication status restrictions or publication date were imposed. Randomized control trials (RCT) and observational studies were included. 
Studies focused on animals, lupus, juvenile or psoriasis arthritis were excluded. Studies that did not include biologics therapy or it was not compared with other pharmacological or conservative treatments, systematic reviews, non-focused on RA patients 'feet, case reports, skin cancer, or studies in other languages rather than English were also excluded.

\subsection{Study Selection}

Study selection was carried out independently by two reviewers in an unblinded, standardized manner. They extracted data from included studies, and disagreements between them were resolved by consensus.

\subsection{Data Extraction and Analysis}

Two reviewers independently screened titles of potentially included studies to identify studies that may have met the inclusion criteria outlined above. Then, the studies were screened via their abstract. Finally, full texts of possibly eligible studies were investigated. Any disagreement between reviewers over the eligibility of studies was discussed with a third reviewer. The data extracted was study details (author, country, and year of publication), sample size (gender, years of age, number of participants with), blinding, follow-up, intervention, measurement instrument used, and results.

Whilst it was an aspiration at the start, due to the heterogeneity of studies and the varying outcomes, a meta-analysis was not appropriate.

\subsection{Risk of Bias in Individual Studies}

Two reviewers worked unblinded to evaluate the risk of bias in individual studies, using the Cochrane Handbook for Systematic Reviews of Interventions (CHSRI) [25] to evaluate randomized control trials (RCT) and the Newcastle-Ottawa Scale (NOS) [28] for observational studies. NOS is a reliable and valid tool to evaluate the quality of any observational design that has an adapted version that has been used by previous systematic reviews [29]. The NOS adapted version assesses the risk of bias, including four domains: Selection bias, performance bias, detection bias, and information bias. Those domains contain seven items, each item is scored from zero (high risk) to three (low risk) points. Therefore, a study is considered a high risk of bias with a total score from 0 to 6 , moderate risk of bias from 7 to 13, and a low risk of bias from 14 to 21 .

Reviewers assessed each RCT taking in account the following domains from the (CHSRI): Bias arising from the randomization process; bias due to deviations from intended interventions; bias due to missing outcome data; bias in the measurement of the outcome and bias in the selection of the reported result. Allocation, blinding, incomplete outcome data, selective reporting, and other potential sources of bias are included in the table.

We used the Review Manager (RevMan) (Computer program). Version 5.3. Copenhagen: The Nordic Cochrane Centre, The Cochrane Collaboration, 2014.

\section{Results}

Searches identified 180 articles, reduced to 155 after duplications were removed. These were screened by title and abstract, and 118 were excluded. The remaining 37 were assessed, and 8 carried forward. Twenty-nine studies were excluded, due to differences in inclusion criteria, as no additional treatment for comparison or use of non-humans, meaning comparison of data would not be possible. Thus, only eight studies fully met the inclusion criteria and were the basis of our review. Three randomized control trials and five observational studies (four retrospective studies and one prospective study). The PRISMA flow diagram is described in Figure 1. 


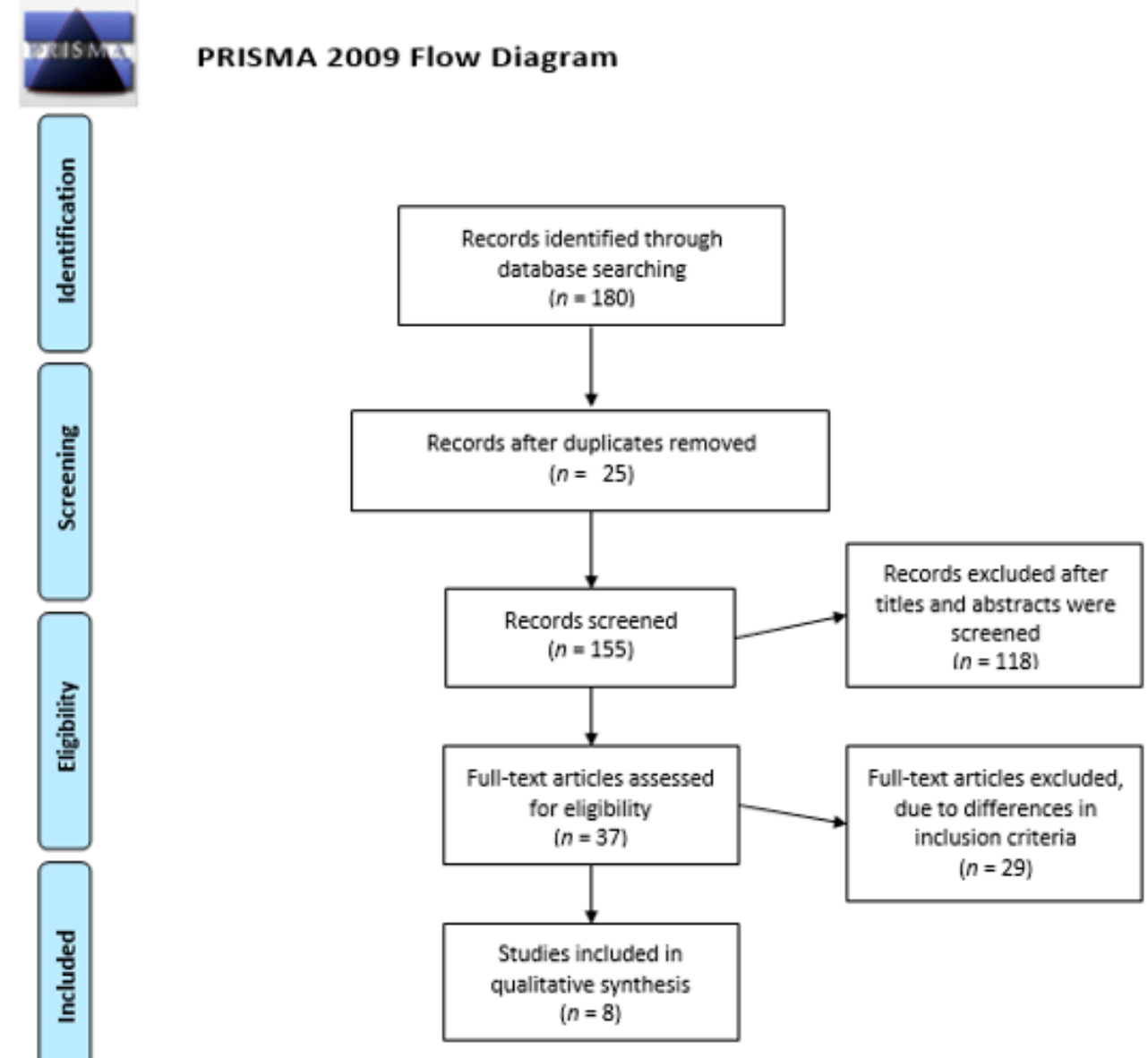

Figure 1. PRISMA flow diagram.

\subsection{Study Characteristics and Syntheses of Results}

They were published in English and between 2004 and 2016. The duration of the intervention was between 12 months and over five years. The total number of participants involved was 1856. Five of the eight studies, include information about gender, showing that 965 participants (51.5\%) were female. One of the RCT had blinded participants (Table 1).

Table 1. Study characteristics.

\begin{tabular}{|c|c|c|c|c|c|c|c|}
\hline Author and Year & Country/Study Type & Sample Size & Blinding & Follow-Up & Intervention & Foot Outcome & Results \\
\hline \multirow[b]{3}{*}{ Tada et al., 2016 [30] } & \multirow[b]{3}{*}{$\begin{array}{l}\text { Japan } \\
\text { Retrospective study }\end{array}$} & 227 patients with RA & \multirow[b]{3}{*}{ No } & \multirow[b]{3}{*}{ Between 2006 and 2013} & \multirow{3}{*}{$\begin{array}{l}\text { Orthopedic surgeries. } \\
\begin{array}{l}\text { Disease Activity } \\
\text { Score (DAS28) }\end{array}\end{array}$} & \multirow{3}{*}{$\begin{array}{l}\text { Surgical site } \\
\text { infection (SSI). } \\
\text { (odds ratio } \\
\text { (OR), 1.11; } \\
p=0.045 \text { ), } \\
\text { Wound healing } \\
\text { (OR, 3.66; } \\
p=0.003 \text { ). }\end{array}$} & \multirow{3}{*}{$\begin{array}{l}\text { Biologics were not risk } \\
\text { factors for } \\
\text { post-operative SSI. } \\
\text { Foot surgery was a risk } \\
\text { factor for delayed } \\
\text { wound healing, due to } \\
\text { the severe foot } \\
\text { deformities, which } \\
\text { causes swelling and } \\
\text { increased skin turgor }\end{array}$} \\
\hline & & $\begin{array}{ll}\bullet & \text { Mean of age } 65.0 \\
& n \text { female }=197(86.7 \%)\end{array}$ & & & & & \\
\hline & & $\begin{array}{l}\text { Rates of biologics and } \\
\text { conventional synthetic } \\
\text { DMARD (csDMARD) } \\
\text { administration were } 30.4 \text { and } \\
91.0 \% \text {, respectively. }\end{array}$ & & & & & \\
\hline Kadota et al., 2016 [31] & $\begin{array}{l}\text { Japan } \\
\text { Retrospective study }\end{array}$ & $\begin{array}{l}204 \text { foot and ankle surgeries in } \\
\text { RA patients. } \\
157 \text { with biologics treatment } \\
\text { and } 47 \text { with csDMARD } \\
\text { treatment. }\end{array}$ & No & $\begin{array}{l}\text { Between } \\
\text { January } 2004 \text { and } \\
\text { December } 2012\end{array}$ & Orthopedic procedures. & $\begin{array}{ll}\text { - SSI (OR), 3.167; } \\
\text { Confidential } \\
\text { Interval (CI), } \\
1.256-7.986 ; \\
p=0.015) . \\
\text { Delayed } \\
\text { wound healing } \\
\text { (DWH) (OR } \\
1.004 ; \mathrm{CI}, \\
1.000-1.007 ; \\
p=0.029)\end{array}$ & $\begin{array}{l}\text { SSI and DWH were } \\
\text { identified in } 8 \text { cases ( } 7 \\
\text { with csDMARD } \\
\text { treatment) and } 3 \text { cases } \\
\text { ( } 2 \text { with csDMARD } \\
\text { treatment), respectively. } \\
\text { Foot and ankle surgery } \\
\text { were associated with an } \\
\text { increased risk of SSI. }\end{array}$ \\
\hline
\end{tabular}


Table 1. Cont.

\begin{tabular}{|c|c|c|c|c|c|c|c|}
\hline Author and Year & Country/Study Type & Sample Size & Blinding & Follow-Up & Intervention & Foot Outcome & Results \\
\hline $\begin{array}{l}\text { Van Herwaarden et al., } \\
2015 \text { [32] }\end{array}$ & $\begin{array}{l}\text { Netherlands } \\
\text { Randomize Control } \\
\text { Trial (RCT) }\end{array}$ & $\begin{array}{l}180 \text { patients with RA: } \\
n=121 \text { with biologics and } \\
\text { dose reduction } \\
\text { • } \quad \text { Mean of age } 59 \\
\text { - } \quad n \text { female }=75(61 \%) \\
n=59 \text { without dose reduction } \\
\text { (usual care). } \\
\text { - } \quad \text { Mean of age } 58 \\
\text { - } \quad n \text { female }=41(69 \%)\end{array}$ & No & 18 months & $\begin{array}{l}\text { Biologics vs. usual care in } \\
\text { RA } \\
\begin{array}{l}\text { DAS28 } \\
\text { Health assessment } \\
\text { questionnaire- } \\
\text { disability index } \\
\text { (HAQ-DI). } \\
\text { EuroQol-5D } \\
\text { Cumulative } \\
\text { incidence of flares }\end{array}\end{array}$ & $\begin{array}{l}\text { - } \quad \text { Radiological } \\
\text { outcomes }\end{array}$ & $\begin{array}{l}\text { Biologics are } \\
\text { non-inferior to usual } \\
\text { care regarding } \\
\text { outcomes }\end{array}$ \\
\hline $\begin{array}{l}\text { Huizinga et al., } 2015 \\
\text { [33] }\end{array}$ & $\begin{array}{l}\text { Multicentre: } \\
\text { Netherlands, UK, Spain, } \\
\text { Germany, Israel, Brazil } \\
\text { USA, Switzerland and } \\
\text { France.RCT }\end{array}$ & $\begin{array}{l}\text { From } 556 \text { randomized patients, } \\
N=279 \text { biologics tocilizumab } \\
\text { (TCZ) + methotrexate (MTX) } \\
\text { (add-on) and } \\
\text { - } \quad n \text { females }=227 \\
\quad \quad(81.9 \%) \\
\text { Mean of age } 53 \\
-\quad n=277 \text { TCZ }+ \\
\text { (Placebo)PBO } \\
\quad \text { (switch). } \\
n \quad \quad n \text { females }=217 \\
\quad(78.6 \%) \\
\text { Mean of age 53.6 } \\
\text { Completed week 104: } \\
n=222 \text { TCZ + MTX (add-on) } \\
n=201 \text { TCZ + PBO (switch). }\end{array}$ & Yes & Over 24 months & 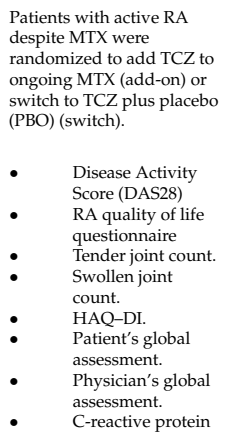 & $\begin{array}{l}\text { Radiographs of } \\
\text { hands/wrists } \\
\text { and feet. } 50.4 \% \\
\text { discontinued } \\
\text { TCZ after } \\
\text { achieving } \\
\text { sustained } \\
\text { remission, and } \\
5.9 \% \text { achieved } \\
\text { drug-free } \\
\text { remission }\end{array}$ & $\begin{array}{l}\text { Most patients } \\
\text { demonstrated minimal } \\
\text { progression of } \\
\text { radiographic structural } \\
\text { damage, with } \\
\text { differences } \\
\text { favoring the add-on } \\
\text { group }(p=0.034) \text {. } \\
\text { Serious adverse events } \\
\text { and serious infections } \\
\text { per } 100 \text { patient-years } \\
\text { were } 12.2 \text { and } 4.4 \text { in } \\
\text { add-on and } 15.0 \text { and } 3.7 \\
\text { in switch patients. }\end{array}$ \\
\hline Kubota et al., 2014 [34] & $\begin{array}{l}\text { Japan } \\
\text { Retrospective study }\end{array}$ & $\begin{array}{l}87 \text { foot and ankle surgeries in } \\
\text { RA patients. } \\
50 \text { with biologics and } 37 \text { with } \\
\text { non-biologics. }\end{array}$ & No & $\begin{array}{l}\text { Between January } 2006 \\
\text { and December } 2011 .\end{array}$ & Orthopedic surgery. & $\begin{array}{ll}- & \text { SSI }(p=0.001), \\
& \text { (OR) 19.27;(CI) } \\
& 4.67-79.45] . \\
- & \text { Late infection }\end{array}$ & $\begin{array}{l}\text { The use of biologics } \\
\text { does not significantly } \\
\text { increase the incidences } \\
\text { of SSI and late infection } \\
\text { after orthopedic surgery }\end{array}$ \\
\hline $\begin{array}{l}\text { Van Vollenhoven et al., } \\
2012[35]\end{array}$ & $\begin{array}{l}\text { Sweden } \\
\text { RCT }\end{array}$ & $\begin{array}{l}487 \text { patients with RA and } \\
\text { previous treatment with MTX. } \\
\text { After 3-4 months, those who } \\
\text { their treatment failed } n=130 \\
\text { (group A) with conventional } \\
\text { treatment } \\
\text { - } \quad \quad \quad \text { Mean of age } 52.9 \\
\quad n \text { female }=101(78 \%) \\
n=128 \text { (group B) with } \\
\text { biologics. } \\
\text { - } \quad n \text { Mean of age } 51.1 \\
\quad n \text { female }=79(76 \%)\end{array}$ & No & 24 months & $\begin{array}{l}\text { Addition of conventional } \\
\text { disease modifying } \\
\text { antirheumatic drugs } \\
\text { (group A) vs. addition of } \\
\text { biologics (group B) vs. } \\
\text { - } \quad \text { DAS28 } \\
\text { HAQ-DI } \\
\text { Health-economic } \\
\text { outcomes }\end{array}$ & $\begin{array}{l}\text { Radiological outcomes } \\
\text { (mean 7.23 Standard } \\
\text { deviation (SD) 12.72) vs. } \\
4 \cdot 00(10 \cdot 0) ; p=0 \cdot 009) .\end{array}$ & $\begin{array}{l}\text { In group B, good } \\
\text { response was } \\
\text { non-significantly } \\
\text { greater than it was in } \\
\text { group A. After } \\
24 \text { months, radiological } \\
\text { disease progression was } \\
\text { greater in patients in } \\
\text { group A than it was in } \\
\text { those in group B } \\
(p=0.009) .\end{array}$ \\
\hline Kubota et al., 2012 [36] & $\begin{array}{l}\text { Japan } \\
\text { Retrospective study }\end{array}$ & $\begin{array}{l}84 \text { foot and ankle surgeries in } \\
\text { RA patients. } \\
47 \text { with biologics and } 37 \text { with } \\
\text { non-biologics }\end{array}$ & No & $\begin{array}{l}\text { Between January } 2006 \\
\text { and December } 2010\end{array}$ & Orthopedic surgery. & $\begin{array}{ll}- & \operatorname{SSI}(p=0.956) \\
& \text { Late infection } \\
(p=0.55)\end{array}$ & $\begin{array}{l}\text { No statistically } \\
\text { significant difference } \\
\text { between groups. The } \\
\text { use of biologics may not } \\
\text { affect the incidence of } \\
\text { post-operative wound } \\
\text { healing and SSI. }\end{array}$ \\
\hline Bibbo et al., 2004 [37] & $\begin{array}{l}\text { USA } \\
\text { Prospective study }\end{array}$ & $\begin{array}{l}n=28 \text { females (90\%) overall } \\
n=16 \text { biologics (group 1) } \\
n=15 \text { not receive biologics } \\
\text { (group 2) }\end{array}$ & No & 12 months & $\begin{array}{l}\text { Risk for healing and } \\
\text { infectious complications } \\
\text { - } \quad \text { smoking history }\end{array}$ & 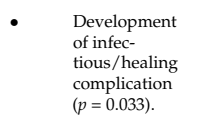 & $\begin{array}{l}\text { Group } 1 \text { demonstrated } \\
\text { a lower complication } \\
\text { rate } \\
(p=0.033) \text { in healing } \\
\text { and infection. }\end{array}$ \\
\hline
\end{tabular}

All the studies included foot related outcomes, as radiographic disease progression, surgical site infection (SSI), development of infection, or wound healing. General health status-related, or RA assessment were also measured using the Health-Assessment Questionnaire (HAQ); the Disease Activity Score (DAS28), and the EuroQol-5D (EQ5D), which includes daily functioning, quality of life, radiographic progression, and adverse events. However, this systematic review is focused on foot outcomes, therefore, this information was not included within our review.

\subsection{Surgical Site Infection}

SSI was assessed in five (62.5\%) of the included studies. SSI outcomes were diagnosed based on the Guideline for the Prevention of Surgical Site Infection [27]. By mutual agreement in all the studies, the use of biologics is not a risk factor for post-operative SSI $[30,31,34,36,37]$. 


\subsection{Delayed Wound Healing}

That outcome was quantified in three of the eight included studies. Delayed wound healing was defined as either delayed suture removal or exhibit impaired healing, and this was judged by physicians $[27,38]$. All the studies concluded that biologics use is not a risk factor for delayed wound healing $[30,31,36]$.

\subsection{Radiographic Progression}

Three studies included outcomes to measure the disease evolution assessed through X-ray to know biologics effects in terms of patients' feet. Radiographs were assessed using the modified Sharp-van der Heijde (SvdH) score (range 0-448; higher scores indicate more joint damage). These values included subscores for erosion (range 0-280) and joint space narrowing (range 0-168) [26]. Also, radiographs were assessed by applying the Genantmodified Sharp Score (GSS). Two different results were found in the included studies: Relevant radiographic progression differences were not found between the groups $[32,33]$ and less radiological disease progression was found in patients with biologics [35].

\subsection{Risk of Bias}

Risk of bias was evaluated using Cochrane guidance within RCT included studies is Figures 2 and 3. All RCTs had low quality in the blinding of participants and personnel, and most RCTs had uncertainty in allocation concealment and blinding of outcome assessment. The risk of bias assessment of observational studies is presented in Table 2, showing one moderate risk of bias study and four low risks of bias studies by NOS adapted version.

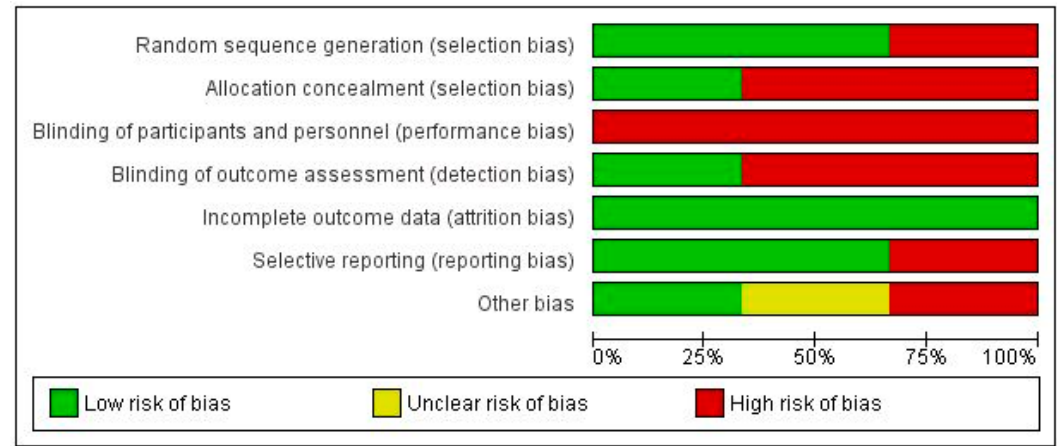

Figure 2. Risk of bias graph.

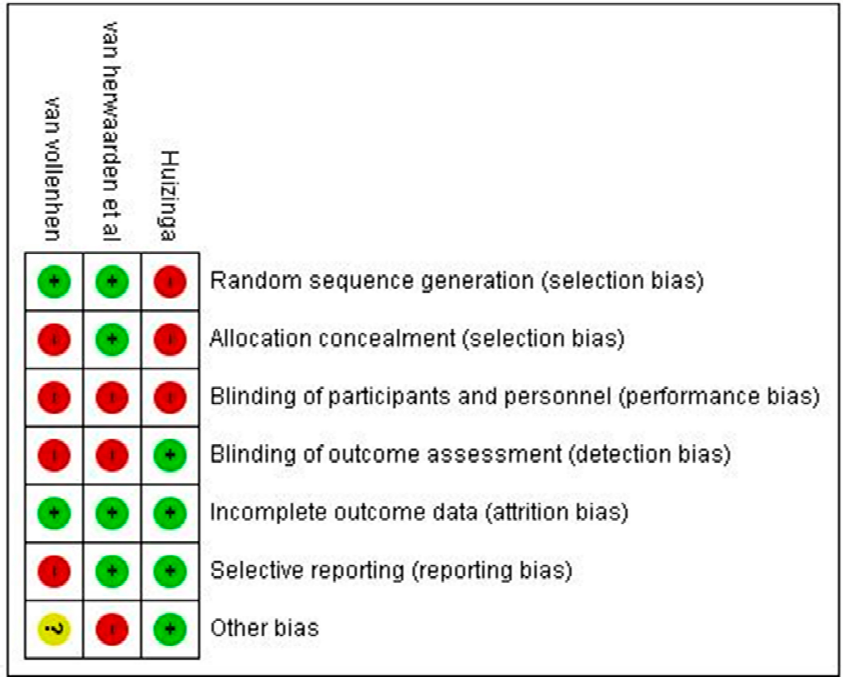

Figure 3. Risk of bias summary. 
Table 2. Risk of bias assessment for observational studies (NOS adapted version).

\begin{tabular}{|c|c|c|c|c|c|c|c|c|}
\hline \multirow{2}{*}{ Study } & \multirow{2}{*}{$\frac{\text { Selection Bias }}{\text { A }}$} & \multicolumn{2}{|c|}{ Performance Bias } & \multicolumn{2}{|c|}{ Detection Bias } & \multicolumn{2}{|c|}{ Information Bias } & \multirow{2}{*}{ Total Score } \\
\hline & & B & $\mathrm{C}$ & D & $\mathbf{E}$ & F & G & \\
\hline Tada et al. [30] & 3 & 2 & 0 & 3 & 3 & 3 & 3 & 17 \\
\hline Kadota et al. [31] & 3 & 1 & 1 & 3 & 3 & 2 & 3 & 16 \\
\hline Kubota et al. [34] & 2 & 1 & 2 & 2 & 3 & 2 & 3 & 15 \\
\hline Kubota et al. [36] & 2 & 1 & 2 & 2 & 3 & 2 & 3 & 15 \\
\hline Bibbo et al. [37] & 1 & 2 & 0 & 0 & 3 & 1 & 2 & 9 \\
\hline
\end{tabular}

Note: $\mathrm{A}=$ Is the source population appropriate and representative of the population of interest?; $\mathrm{B}=$ Is the sample size adequate, and is there sufficient power to detect a meaningful difference in the outcome of interest?; $\mathrm{C}=$ Did the study identify and adjust for any variables or confounders that may influence the outcome?; $\mathrm{D}=$ Did the study use appropriate statistical analysis methods relative to the outcome of interest?; $\mathrm{E}=$ Is there little missing data, and did the study handle it accordingly?; F = Is the methodology of the outcome measurement explicitly stated, and is it appropriate?; $\mathrm{G}=$ Is there an objective assessment of the outcome of interest?

\section{Discussion}

The main aim of our systematic review was to evaluate the evidence for changes in foot outcomes in patients with RA using biologics. From the review above, key findings emerge: Longitudinal analyses reported that the use of biologics may not be a risk factor for post-operative surgical site infection or delayed wound healing, and there are no differences between biologics and non-biologics in terms of radiographic progression. Those are some important findings in the understanding of the biologics effect on RA patients' feet.

Our initial hypothesis was that the use of biologics could benefit patients with RA in terms of their feet, such as reducing foot pain, and therefore, improving quality of life. Most patients with RA report foot symptoms during the process of the disease, foot pain being the most common [6]. Whilst based on suitable studies, our analysis of eight studies involving almost 2000 participants did not report any changes in terms of foot pain. Their outcomes are related to feet, including radiographic disease progression, SSI, development of infectious or wound healing. The included studies evaluated pain and quality of life from a holistic patient perspective. Those studies concluded that biologics can be used to improve patients' pain, but there was no specific indication of foot pain. A previous qualitative study explored the personal experiences of patients with RA in receipt of biologics, in terms of their feet. In this qualitative research, patients described that before biologics, they felt more pain and disabling symptoms. Also, patients declared that their function and mobility were restored. However, patients reported that foot pain remained, which could be explained by the established deformity or foot surgeries [39]. There is a lack of experimental studies focused on foot pain outcomes in RA patients receiving biologics.

Regarding the gender influence in our included studies, this information could not be found in all of them. Only five studies provide data related to sex difference, showing that most of the overall participants were female $[30,32,33,35,37]$. This fact agrees with the previous findings of RA, which identifies that the disease is more common in women than men (3:1) [40]. A prior review about gender influence in RA demonstrated that males and females approach their pathology differently. The presence of comorbidities, such as fibromyalgia, a different immune response, major depression, hormonal differences, and osteoporosis, are more frequent in females [41]. It may influence the results; therefore, it is necessary to distinguish results from females and males in future research.

It has been suggested that patients with biologics have an extensive risk of postoperative infection [42], and the British Society for Rheumatology (BSR) have developed guidelines for the management of the biologic agent Tocilizumab. BSR claims that it is necessary to balance the risks of post-operative infection against the risks of a post-operative disease flare [43]. Some studies are investigating the risks associated with discontinuation of biologics vs. the resultant infection risk after surgery. Our findings on post-operative infection suggest that the use of biological is not a risk factor for post-operative infection in foot and ankle surgery. Tada et al. in 2016 [30], in their retrospective study among 227 patients with RA after 332 elective orthopedic surgeries, concluded that biologics 
were not risk factors for post-operative SSI. They concluded that the risk factor for postoperative SSI was foot surgery, due to the severe foot deformities, which causes swelling and increased skin turgor. Kadota et al. [31] also found similar results, which provides support for the present findings. Therefore, surgeons and healthcare professionals who are involved in wound care need to be aware that foot surgery may be associated with SSI complications.

Previous studies reported that there is conflict related to continuing or stopping biologic drug therapy prior to orthopedic procedures in terms of avoiding the possible side effects of these drugs in delayed wound healing [44]. Previous in vivo studies, focused on the overall impact of biologics upon wound healing, showed that biologics suppress the promotion of key structural proteins, but help to collagen synthesis [45,46]. Nevertheless, a real environment is not considered in vivo studies. Included studies, within a real orthopedic surgery process, concluded that biologics use is not a risk factor for delayed wound healing $[30,31,36]$.

The assessment to determine bias within the observational studies, which we included, demonstrated four low risk, and one moderate risk study. The studies also contained missing data, such as activity remission, and the authors also showed a conflict of interest. The risk of bias within the randomized control trials included in this review, presented incomplete outcome data and a lack of blinding. There was a large difference between the number of included participants in the studies, the lowest of which being 31 [37], and the highest being 556 [33]. One of the strengths of this review is the use of specific review tools and checklists to evaluate the risk of bias.

The clinical implications of our results may help in the therapy election for patients with RA in terms of their feet, considering the benefits in the feet radiographic progression. The applicability of these new results is also shown in the perioperative process.

The main limitation is that we have focused our review on biologics on foot outcomes instead of the effectivity of all therapies for RA on patients' foot. Due to the nature of the study, groups were very heterogeneous, and sometimes information, such as the types of surgery performed or if biologics were stopped peri-operatively, which may have an impact on SSI following surgery, were not clear. Another limitation of the present study is the difficulty related to finding papers that relate to the topic of our study. This is due to the ambiguity in the studies related to RA, which mention feet, however, the aim of the study is not foot related. This makes it impossible to analyze the repercussion of biologics in terms of feet patients.

\section{Conclusions}

The included studies suggest that the use of biologics slows the rate of foot joint erosion. Our review shows that biologics are not a risk for surgical site infection or delayed wound healing after foot and ankle surgery. However, as the included studies do not define if the use of biologics stopped prior to the surgery, results should be taken into consideration with caution. More research focused on biologics effect on foot pain is needed. We strongly suggest that biologics continue to be studied in experimental settings for the treatment of foot pathology in RA patients. Due to the diversity within the methodology of the included studies, results should be taken into consideration with caution. Thus, more rigorous and larger studies are needed.

Author Contributions: Conceptualization, L.R.-P., A.R.-C., A.B.O.-A., C.J.N. and G.G.-N.; Formal analysis, L.R.-P. and P.N.-G.; Methodology, G.G.-N., A.B.O.-A. and L.R.-P.; Writing-original draft, G.G.-N., A.B.O.-A., A.R.-C. and L.R.-P.; Writing-review \& editing, C.J.N., A.B.O.-A., and G.G.-N. All authors have read and agreed to the published version of the manuscript.

Funding: This research received no external funding.

Institutional Review Board Statement: Not applicable.

Informed Consent Statement: Not applicable.

Data Availability Statement: Data sharing not applicable. 
Conflicts of Interest: All the authors declare that they have no conflict of interest derived from the research, authorship, and/or publication of this study.

\section{Appendix A Search Strategies}

Database: Ovid MEDLINE(R) and Epub Ahead of Print, In-Process \& Other NonIndexed Citations, Daily and Versions(R) (1946 to April 08, 2020)

\section{Search Strategy:}

1. exp Arthritis, Rheumatoid/ (111898)

2. $\quad \exp$ Foot Joints/or exp Foot/ (62425)

3. exp Biological Therapy/ (663983)

4. 1 and 2 and 3 (18)

Database CINAHL:

rheumatoid arthritis AND foot AND (biologics OR biological therapy) (33)

Database Cochrane Library:

rheumatoid arthritis AND foot AND (biologics OR biological therapy) in Title Abstract Keyword (23)

Database Evidence Search:

rheumatoid arthritis AND foot AND (biologics OR biological therapy) (40)

Database Pubmed:

(((rheumatoid arthritis) AND (foot OR feet)) AND (biologics)) AND (biological therapy) (67)

Database Web of Science:

((rheumatoid) arthritis AND foot) AND (biologics) OR biological therapy))

\section{References}

1. Raza, K.; Buckley, C.E.; Salmon, M.; Buckley, C.D. Treating very early rheumatoid arthritis. Best Pract. Res. Clin. Rheumatol. 2006, 20, 849-863. [CrossRef] [PubMed]

2. Vamos, M.; White, G.L.; Caughey, D.E. Body image in rheumatoid arthritis: The relevance of hand appearance to desire for surgery. Br. J. Med. Psychol. 1990, 63, 267-277, Erratum in 1990, 63 Pt 4, 401. [CrossRef] [PubMed]

3. Hill, J.; Bird, H.; Thorpe, R. Effects of rheumatoid arthritis on sexual activity and relationships. Rheumatology 2003, 42, 280-286. [CrossRef] [PubMed]

4. Villamizar-Villamizar, J.P.; Serrano-Torres, F.; Ayala, J.; Bautista, N. Evaluación de la calidad de vida en pacientes con artritis reumatoide. Horiz. Med. 2015, 15, 76-77. [CrossRef]

5. Turner, D.E.; Woodburn, J.; Helliwell, P.S.; Cornwall, M.W.; Emery, P. Pes planovalgus in RA: A descriptive and analytical study of foot function determined by gait analysis. Musculoskeletal Care 2003, 1, 21-33. [CrossRef]

6. Otter, S.J.; Lucas, K.; Springett, K.; Moore, A.; Davies, K.; Cheek, L.; Young, A.; Walker-Bone, K. Foot pain in rheumatoid arthritis prevalence, risk factors and management: An epidemiological study. Clin. Rheumatol. 2010, 29, 255-271. [CrossRef]

7. Grondal, L.; Tengstrand, B.; Nordmark, B.; Wretenberg, P.; Stark, A. The foot: Still the most important reason for walking incapacity in rheumatoid arthritis—Distribution of symptomatic joints in 1000 RA patients. Acta Orthop. 2008, 79, 257-261. [CrossRef]

8. Otter, S.J.; Lucas, K.; Springett, K.; Moore, A.; Davies, K.; Young, A.; Walker-Bone, K. Comparison of foot pain and foot care among rheumatoid arthritis patients taking and not taking anti-TNF $\alpha$ therapy: An epidemiological study. Rheumatol. Int. 2011, 31, 1515-1519. [CrossRef]

9. Juan Mas, A. La terapia biológica en las enfermedades reumáticas. Med. Balear 2008, 23, 11-16.

10. NICE. Rheumatoid Arthritis in Adults: Management. Available online: https://www.nice.org.uk/guidance/qs33 (accessed on 12 June 2020).

11. Scott, D.L.; Wolfe, F.; Huizinga, T.W.J. Lancet Rheumatoid arthritis. Comorbidity Rheum. Dis. 2017, 376, 53-79. [CrossRef]

12. Lard, L.R.; Visser, H.; Speyer, I.; Vander Horst-Bruinsma, I.E.; Zwinderman, A.H.; Breedveld, F.C.; Hazes, J.M.W. Early versus delayed treatment in patients with recent-onset rheumatoid arthritis: Comparison of two cohorts who received different treatment strategies. Am. J. Med. 2001, 111, 446-451. [CrossRef]

13. Nell, V.P.K.; Machold, K.P.; Eberl, G.; Stamm, T.A.; Uffmann, M.; Smolen, J.S. Benefit of very early referral and very early therapy with disease-modifying anti-rheumatic drugs in patients with early rheumatoid arthritis. Rheumatology 2004, 43, 906-914. [CrossRef] [PubMed]

14. Sanmartí, R.; García-Rodríguez, S.; Álvaro-Gracia, J.M.; Andreu, J.L.; Balsa, A.; Cáliz, R.; Fernández-Nebro, A.; Ferraz-Amaro, I.; Gómez-Reino, J.J.; González-Álvaro, I.; et al. 2014 Update of the Consensus Statement of the Spanish Society of Rheumatology on the Use of Biological Therapies in Rheumatoid Arthritis. Reumatol. Clin. (Engl. Ed.) 2015, 11, 279-294. [CrossRef] 
15. Saag, K.G.; Gim, G.T.; Patkar, N.M.; Anuntiyo, J.; Finney, C.; Curtis, J.R.; Paulus, H.E.; Mudano, A.; Pisu, M.; Elkins-Melton, M.; et al. American College of Rheumatology 2008 recommendations for the use of nonbiologic and biologic disease-modifying antirheumatic drugs in rheumatoid arthritis. Arthritis Care Res. 2008, 59, 762-784. [CrossRef]

16. Hirano, Y.; Kojima, T.; Kanayama, Y.; Shioura, T.; Hayashi, M.; Kida, D.; Kaneko, A.; Eto, Y.; Ishiguro, N. Influences of antitumour necrosis factor agents on postoperative recovery in patients with rheumatoid arthritis. Clin. Rheumatol. 2010, 29, 495-500. [CrossRef]

17. Scrivo, R.; Conti, F.; Spinelli, F.R.; Truglia, S.; Magrini, L.; Di Franco, M.; Ceccarelli, F.; Valesini, G. Switching between TNF $\alpha$ antagonists in rheumatoid arthritis: Personal experience and review of the literature. Reumatismo 2009, 61, 107-117. [CrossRef]

18. Okamoto, H.; Shidara, K.; Hoshi, D.; Kamatani, N. Anti-arthritis effects of vitamin K 2 ( menaquinone-4) -A new potential therapeutic strategy for rheumatoid arthritis. FEBS J. 2007, 2, 4588-4594. [CrossRef]

19. Kornør, H.; Burger, E.; Harboe, I.; Klemp, M. Biologics for Early Rheumatoid Arhritis; Norwegian Knowledge Centre for the Health Services: Oslo, Norway, 2010.

20. Taylor, P.C.; Feldmann, M. Anti-TNF biologic agents: Still the therapy of choice for rheumatoid arthritis. Nat. Rev. Rheumatol. 2009, 5, 578-582. [CrossRef]

21. Kulp, W.; Corzillus, M.; Greiner, W.; Pientka, L.; Siebert, U.; von der Schulenburg, J.-M.; Wasem, J. Influence of tumor necrosis factor $\alpha$ in rheumatoid arthritis. GMS Health Technol. Assess. 2005, 1, Doc12.

22. Björk, M.; Thyberg, I.; Valtersson, E.; Östlund, G.; Stenström, B.; Sverker, A. Foot Barriers in Patients With Early Rheumatoid Arthritis: An Interview Study Among Swedish Women and Men. Arthritis Care Res. 2018, 70, 1348-1354. [CrossRef]

23. Gijon-Nogueron, G.; Ramos-Petersen, L.; Ortega-Avila, A.B.; Morales-Asencio, J.M.; Garcia-Mayor, S. Effectiveness of foot orthoses in patients with rheumatoid arthritis related to disability and pain: A systematic review and meta-analysis. Qual. Life Res. 2018, 27, 3059-3069. [CrossRef] [PubMed]

24. Liberati, A.; Altman, D.G.; Tetzlaff, J.; Mulrow, C.; Gøtzsche, P.C.; Ioannidis, J.P.A.; Clarke, M.; Devereaux, P.J.; Kleijnen, J.; Moher, D. The PRISMA statement for reporting systematic reviews and meta-analyses of studies that evaluate health care interventions: Explanation and elaboration. J. Clin. Epidemiol. 2009, 62, e1-e34. [CrossRef] [PubMed]

25. Higgins, J.P.T.; Green, S. (Eds.) Cochrane Handbook for Systematic Reviews of Interventions; John Wiley \& Sons Ltd.: Hoboken, NJ, USA, 2019.

26. Van Der Heijde, D. How to read radiographs according to the Sharp/van der Heijde method. J. Rheumatol. 2000, 27, 261-263. [PubMed]

27. Mangram, A.J.; Horan, T.C.; Pearson, M.L.; Silver, L.C.; William, R. Guideline for prevention of surgical site infection. Bull. Am. Coll. Surg. 2000, 85, 23-29.

28. Shea, B.; Robertson, J.; Peterson, J.; Welch, V.; Losos, M. The Newcastle-Ottawa Scale (NOS) for Assessing the Quality of Nonrandomized Studies in Meta-Analysis Bias and Confounding Newcastle-Ottowa Scale. Available online: http://www. evidencebasedpublichealth.de/download/Newcastle_Ottowa_Scale_Pope_Bruce.pdf (accessed on 24 May 2020).

29. Bawor, M.; Dennis, B.B.; Bhalerao, A.; Plater, C.; Worster, A.; Varenbut, M.; Daiter, J.; Marsh, D.C.; Desai, D.; Steiner, M.; et al. Sex differences in outcomes of methadone maintenance treatment for opioid use disorder: A systematic reviewand meta-analysis. CMAJ Open 2015, 3, E344-E351. [CrossRef]

30. Tada, M.; Inui, K.; Sugioka, Y.; Mamoto, K.; Okano, T.; Kinoshita, T.; Hidaka, N.; Koike, T. Delayed wound healing and postoperative surgical site infections in patients with rheumatoid arthritis treated with or without biological disease-modifying antirheumatic drugs. Clin. Rheumatol. 2016, 35, 1475-1481. [CrossRef]

31. Kadota, Y.; Nishida, K.; Hashizume, K.; Nasu, Y.; Nakahara, R.; Kanazawa, T.; Ozawa, M.; Harada, R.; Machida, T.; Ozaki, T. Risk factors for surgical site infection and delayed wound healing after orthopedic surgery in rheumatoid arthritis patients. Mod. Rheumatol. 2016, 26, 68-74. [CrossRef]

32. Van Herwaarden, N.; Van Der Maas, A.; Minten, M.J.M.; Van Den Hoogen, F.H.J.; Kievit, W.; Van Vollenhoven, R.F.; Bijlsma, J.W.J.; Van Den Bemt, B.J.F.; Den Broeder, A.A. Disease activity guided dose reduction and withdrawal of adalimumab or etanercept compared with usual care in rheumatoid arthritis:Open label, randomised controlled, non-inferiority trial. BMJ 2015, 350, 1-8. [CrossRef]

33. Huizinga, T.W.J.; Conaghan, P.G.; Martin-Mola, E.; Schett, G.; Amital, H.; Xavier, R.M.; Troum, O.; Aassi, M.; Bernasconi, C.; Dougados, M. Clinical and radiographic outcomes at 2 years and the effect of tocilizumab discontinuation following sustained remission in the second and third year of the ACT-RAY study. Ann. Rheum. Dis. 2015, 74, 35-43. [CrossRef]

34. Kubota, A.; Sekiguchi, M.; Nakamura, T.; Miyazaki, Y.; Suguro, T. Does use of a biologic agent increase the incidence of postoperative infection in surgery for rheumatoid arthritis after total joint arthroplasty? Mod. Rheumatol. 2014, 24, 430-433. [CrossRef]

35. Van Vollenhoven, R.F.; Geborek, P.; Forslind, K.; Albertsson, K.; Ernestam, S.; Petersson, I.F.; Chatzidionysiou, K.; Bratt, J. Conventional combination treatment versus biological treatment in methotrexate-refractory early rheumatoid arthritis: 2 Year follow-up of the randomised, non-blinded, parallel-group Swefot trial. Lancet 2012, 379, 1712-1720. [CrossRef]

36. Kubota, A.; Nakamura, T.; Miyazaki, Y.; Sekiguchi, M.; Suguro, T. Perioperative complications in elective surgery in patients with rheumatoid arthritis treated with biologics. Mod. Rheumatol. 2012, 22, 844-848. [CrossRef] [PubMed]

37. Bibbo, C.; Goldberg, J.W. Infectious and healing complications after elective orthopaedic foot and ankle surgery during tumor necrosis factor-alpha inhibition therapy. Foot Ankle Int. 2004, 25, 331-335. [CrossRef] [PubMed] 
38. Scanzello, C.R.; Figgie, M.P.; Nestor, B.J.; Goodman, S.M. Perioperative management of medications used in the treatment of rheumatoid arthritis. HSS J. 2006, 2, 141-147. [CrossRef] [PubMed]

39. Sanders, L.; Donovan-Hall, M.; Borthwick, A.; Bowen, C.J. Experiences of mobility for people living with rheumatoid arthritis who are receiving biologic drug therapy: Implications for podiatry services. J. Foot Ankle Res. 2017, 10, 1-9. [CrossRef]

40. Myasoedova, E.; Crowson, C.S.; Kremers, H.M.; Therneau, T.M.; Gabriel, S.E. Is the incidence of rheumatoid arthritis rising? Results from Olmsted County, Minnesota, 1955-2007. Arthritis Rheum. 2010, 62, 1576-1582. [CrossRef]

41. Favalli, E.G.; Biggioggero, M.; Crotti, C.; Becciolini, A.; Raimondo, M.G.; Meroni, P.L. Sex and Management of Rheumatoid Arthritis. Clin. Rev. Allergy Immunol. 2019, 56, 333-345. [CrossRef]

42. Kawakami, K.; Ikari, K.; Kawamura, K.; Tsukahara, S.; Iwamoto, T.; Yano, K.; Sakuma, Y.; Tokita, A.; Momohara, S. Complications and features after joint surgery in rheumatoid arthritis patients treated with tumour necrosis factor- $\alpha$ blockers: Perioperative interruption of tumour necrosis factor-a blockers decreases complications? Rheumatology 2010, 49, 341-347. [CrossRef]

43. Malaviya, A.P.; Ledingham, J.; Bloxham, J.; Bosworth, A.; Buch, M.; Choy, E.; Cope, A.; Isaacs, J.; Marshall, D.; Wright, G.; et al. The 2013 BSR and BHPR guideline for the use of intravenous tocilizumab in the treatment of adult patients with rheumatoid arthritis. Rheumatology 2014, 53, 1344-1346. [CrossRef]

44. Diaper, R.; Wong, E.; Metcalfe, S.A. The implications of biologic therapy for elective foot and ankle surgery in patients with rheumatoid arthritis. Foot 2017, 30, 53-58. [CrossRef]

45. Goldberg, M.T.; Han, Y.P.; Yan, C.; Shaw, M.C.; Garner, W.L. TNF- $\alpha$ suppresses $\alpha$-smooth muscle actin expression in human dermal fibroblasts: An implication for abnormal wound healing. J. Investig. Dermatol. 2007, 127, 2645-2655. [CrossRef] [PubMed]

46. Salomon, G.D.; Kasid, A.; Cromack, D.T.; Director, E.; Talbot, T.L.; Sank, A.; Norton, J.A. The local effects of cachectin/tumor necrosis factor on wound healing. Ann. Surg. 1991, 214, 175-180. [CrossRef] [PubMed] 